\title{
Role of Education on Poverty Reduction: The Case Study of Pakistan
}

\author{
Chenyi Zhang
}

Branksome Hall School
jzhang3@branksome.on.ca

\begin{abstract}
Pakistan has the sixth-largest population in the world; its poverty issue attracts more attention. Education is indispensable to economic development and poverty eradication. No economic growth and poverty alleviation are possible without education. Hence it is crucial to seek the effect of education upon poverty in Pakistan. This study evaluates Pakistan poverty and education situation, education system, and analysis the role of education in poverty. In the end, we provide several recommendations for government to address current issues in order to improve education level and reduce poverty rate, for example, manage current education system, widespread literacy, support rural low-income family education, provide more grant for educational materials and develop education programs.
\end{abstract}

Keywords: Education, Poverty, Low-income, Pakistan

\section{INTRODUCTION}

Economic growth has been considered as a vital indicator of the success of economic development in many countries. For example, income per capita is an indicator of develop progress. Human capital is considered as a key part of development. Mincer (1958), Goode (1959), Schultz (1961) and Becker (1975) provided different insights into the definition of human capital. Generally speaking, there are many ingredients of human capital, i.e. education, health, job training, skills etc. However, education serves as an essential tool to reduce poverty and stimulate economic growth. Mankiw et al. (1992) firstly used human capital in production function which indicated that higher human capital level leads to higher growth level. One important issue that has attracted much attention from researchers is whether education can be a powerful instrument in reducing poverty in developing countries. Poverty attracts world's most significant attention, and governments take reducing poverty rate as their goals. Sachs (2009) pointed out more than eight million poor people die each year around world. The United Nation Development Project (UNDP) estimated about 1.4 billion people who were in extreme poverty situation live in three regions; East Asia, South Asia and Sub-Saharan Africa. Poverty not only prevents economic development but induces problems like violence, conflict, crime and terrorism.
As we know, poverty and education are strongly correlated, for example, parents seem to be reluctant to send their children for education because of poverty. Nasir et al. (2016) pointed out it is significant to study the poverty problem in context of education since effective education can alleviate poverty. Observations show that many Pakistanis are living below the poverty level of one US dollar per day. Ishaq Dar Finance Minister of Pakistan declared that over half of the Pakistan population was living below the poverty line in 2014. Studying the relationship between education, poverty, and economic growth in Pakistan seems to be very important.

\section{POVERTY IN PAKISTAN}

\subsection{The big gap of GDP per capita between Pakistan and the US.}

GDP per capita is "A measure of the total output of a country that takes the gross domestic product (GDP) and divides it by the number of people in the country." It is also an effective indicator of economic performance and a functional unit to make cross-country comparisons of economic wellbeing and poverty status. From World Bank data, we could clearly see that the GDP per capita gap between the US and Pakistan was becoming more extensive in recent years. Compared to the developed country, Pakistan falls behind a lot. From Figure 2, the difference was about 20,000 dollars, however, in 2019, 
the gap increased to around 65,000. It is crucial for Pakistan government to make economic progress.

Beside lower GDP level, the poverty situation in Pakistan is severe as well. According to Asian Development Bank, in Pakistan, $24.3 \%$ of the population lives below the national poverty line in 2015 , the proportion of employed population below $\$ 1.90$ purchasing power parity a day in 2019 is $2.3 \%$. For every 1,000 babies born in Pakistan in 2018, 69 die before their 5 th birthday.

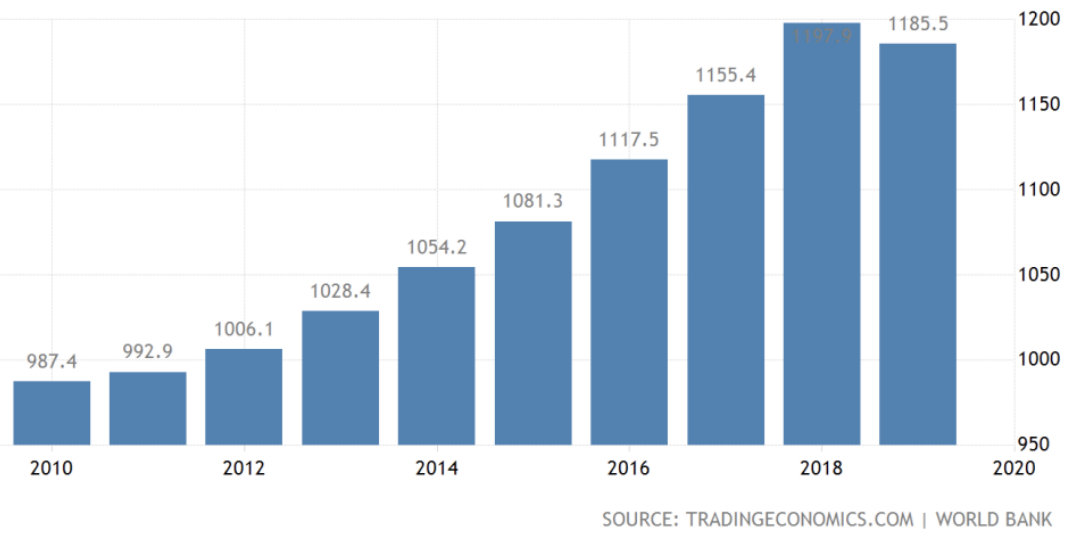

Figure 1: Pakistan DGP per capita over Time

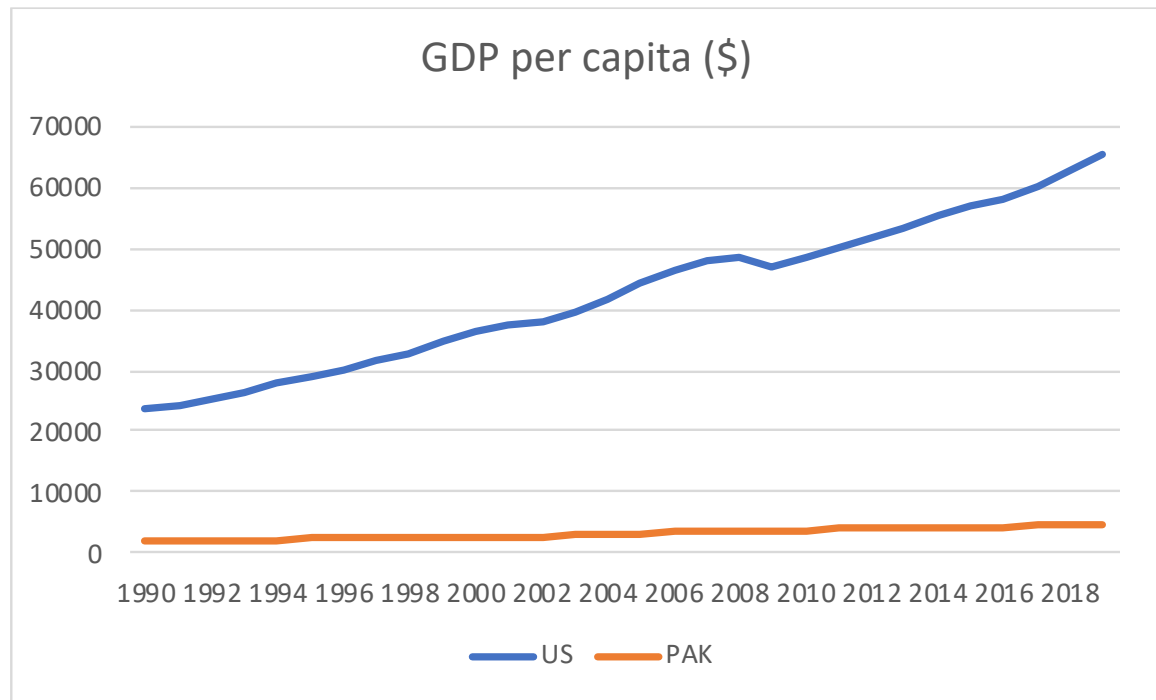

Figure 2: Comparison of US and Pakistan GDP per capita

Source: World Bank

\subsection{Poverty Situation}

Beside lower GDP level, the poverty situation in Pakistan is severe as well. According to Asian Development Bank, in Pakistan, $24.3 \%$ of the population lives below the national poverty line in 2015, the proportion of employed population below $\$ 1.90$ purchasing power parity a day in 2019 is $2.3 \%$. For every 1,000 babies born in Pakistan in 2018, 69 die before their 5th birthday. In detail, for example, sixty percent of Pakistanis struggle to find food to eat and poverty is the primary reason for Pakistan's rate of child labor. 


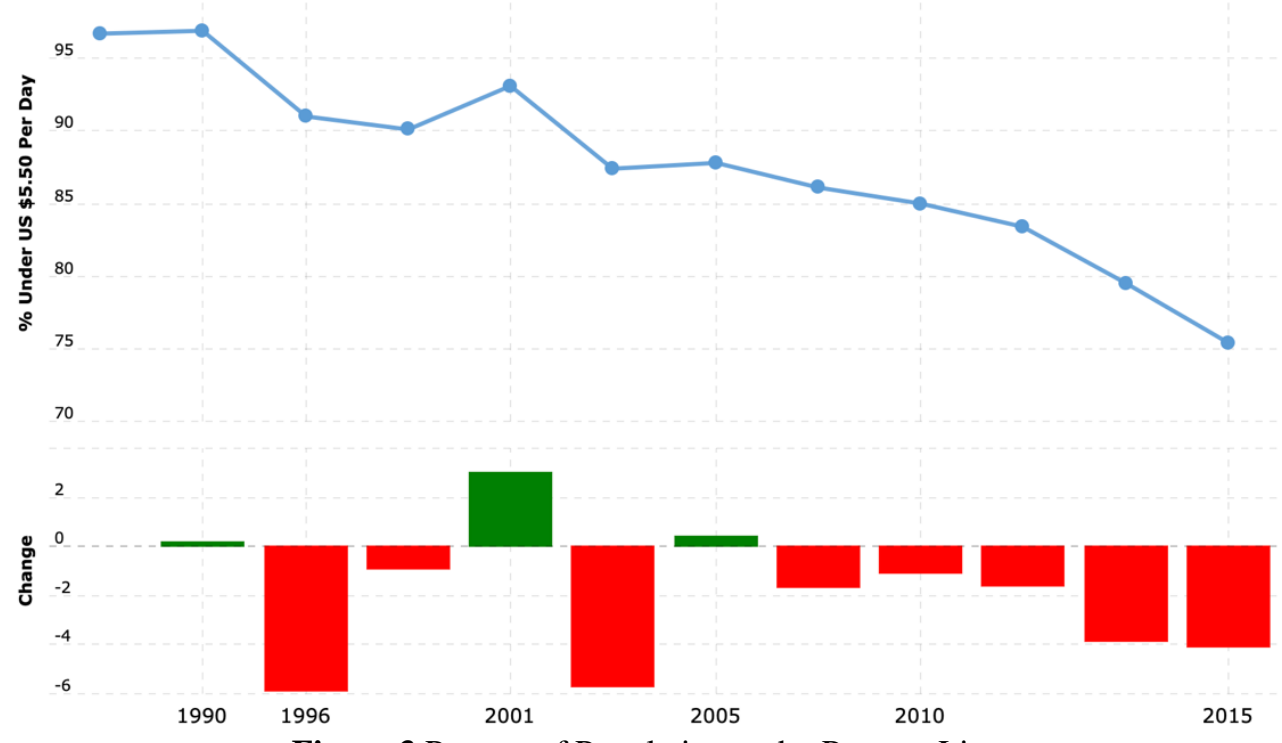

Figure 3 Percent of Population under Poverty Line

Source: Asian Development Bank

According to Malik (2010), poverty was one of the crucial challenges in Pakistan, which influenced a large majority of population was living below the poverty line. From Figure 3, poverty in Pakistan has been rising and falling in different periods. For example, poverty rate was lower in 1996 and 2015, but it rose in 2001. The poverty rate declined by 40 percent over the last two decades to 24.3 percent in 2015 , however, IMF project shows a significant reversal during COVID-19 pandemic this year, with up to 40 percent of Pakistanis living below the poverty line.

Poverty climbing can sometimes because of hunger, inadequate income, powerlessness, poor education and disease. For example, the chances of the children becoming non-poor are limited in poor family. The parent who is poor lacks money to educate the children. Hence, less education will make poor people hard to change the current unsatisfactory situation. Here, we will focus on the role of education in alleviating poverty.

\section{EDUCATION IN PAKISTAN}

\subsection{Literacy Rate}

Some researchers recommend that in order to reduce poverty, what government can do it to provide education and training to make people competitive. These were the only solutions to solve poverty problem. Chambel \& Hartl (2011) emphasize the importance of technical education and training. Acquiring more skills help the poor to come out of poverty. Nagi (2012) also point out that it was necessary to give priority to the technical education and vocational training.

Current education in Pakistan is incompatible with the societal needs. At the same time, the education system is irrelevant and conventional which let graduates who could not find suitable jobs in the job market. Pakistan is one of the most illiterate countries in the world. Though it attained literacy rate of 60 percent in the past 35 years, the process with a plodding pace, and it could not achieve the required literacy rates. Even in the SAARC regions, Pakistan is among the lowest-performing countries. From Figure 4 and Table 1, we could see some features by gender and age. In general, female attained lower literacy rate than male, in 2017 , the gap is about $10 \%$ in all age groups. The largest gap is from age group 15 years and older which indicates that as children grow up, less female quit their school due to some reasons, for example, parents don't have enough money to afford tuition, conventional concerns about women don't need so much knowledge and government just provide free and compulsory education to all citizen of age five to sixteen years. 


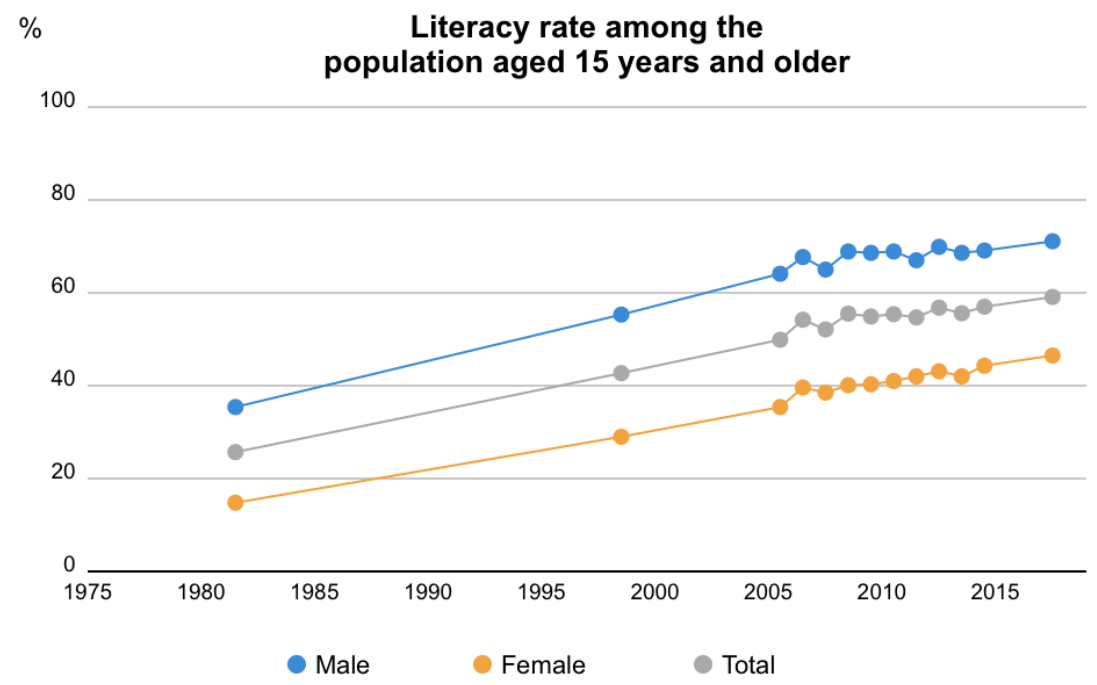

Figure 4 Pakistan Literacy rate over Time

Source: http://uis.unesco.org/en/country/pk

Table 1 Pakistan Literacy Rate by Gender and Age

\begin{tabular}{|c|c|c|c|c|}
\hline & TOTAL & MALE & FEMALE & \\
\hline \multicolumn{5}{|l|}{ Literacy rate (\%) } \\
\hline $15-24$ years & 74.5 & 81.3 & 67.5 & (2017) \\
\hline 15 years and older & $59.1:$ & 71.1 & 46.5 & (2017) \\
\hline 65 years and older & 27.1 & 38.1 & 10.7 & (2017) \\
\hline
\end{tabular}

Source: http://uis.unesco.org/en/country/pk

\subsection{School System}

The education system in Pakistan is generally divided into six levels, as showed in Table 2: preschool primary, middle, high, intermediate (grades eleven and twelve, leading to a Higher Secondary School Certificate or HSSC), and university programs leading to undergraduate and graduate degrees. Technical education and vocational training were the best way of addressing the issue of poverty, but in Pakistan, more stress is on general type of theoretical conventional education. Malik (2010) show that institutions for vocational education and technical training were only 1,522 in Pakistan, including both public and private institutions from which only a small portion of trained graduates come out.

Table 2 Types of School in Pakistan

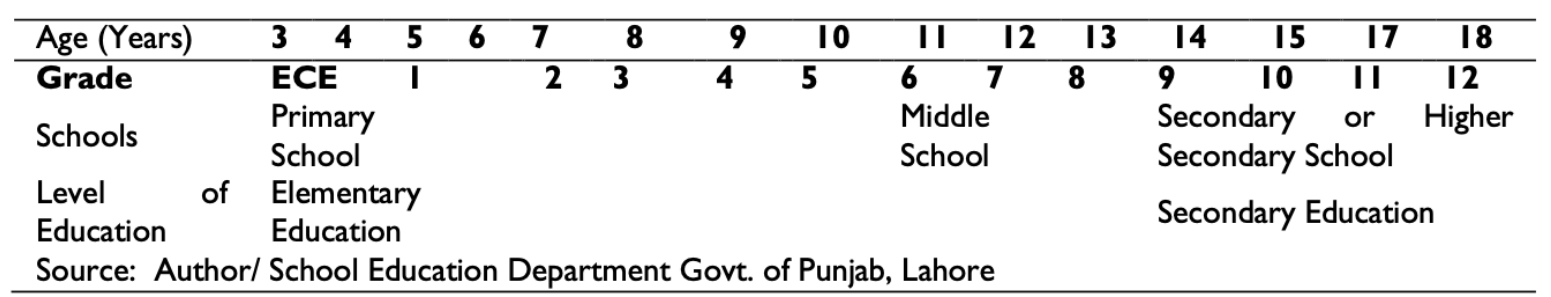

Not only lack of vocational education and technical training, Pakistan is having a large number of out-of-school children. If Pakistan wants reduce poverty, it should educate and skill surging youth population to fuel the country's economic growth. About 22 percent of Pakistani children age 1-5 and 70 percent of age 9-12 did not participate in education in 2017.
Gender inequalities should be noticed when considering the out-of-school situation. According to Human Rights Watch, only 41 percent of girls participate in education, compared with 51 percent of boys in grade six. And by grade nine, merely 13 percent of young women are still enrolled. Poverty also plays a significant role. Particularly in rural areas, parents often 
cannot afford the costs related to education. Here again, the results are devastating, particularly for girls, who are frequently kept at home to cook and do housework which is common in developing countries.

\begin{tabular}{|c|c|c|c|}
\hline \multicolumn{4}{|c|}{ Out-of-School Children by Stages of Education (in Millions) } \\
\hline $\begin{array}{l}\text { STAGE OF EDUCATION } \\
\text { (GRADES) }\end{array}$ & ENROLLED & OUT-OF-SCHOOL & $\begin{array}{l}\text { PERCENTAGE } \\
\text { OUT OF SCHOOL }\end{array}$ \\
\hline Elementary (1-5) & 18.4 & 5.0 & 21.3 \\
\hline Middle (6-8) & 6.3 & 6.5 & 50.9 \\
\hline Secondary (9-12) & 4.8 & 11.3 & 70.0 \\
\hline Iroe: Ministry of Federal Education and Profe & & (c) $202 C$ & n Services \\
\hline
\end{tabular}

Figure 5 Out-of-School Children in Pakistan

\section{ROLE OF EDUCATION IN POVERTY}

The most powerful antidote of poverty is education. Montecel (2013) indicates that a person having more education has less risk of falling in poverty. Education enables individuals to know their potential and give people opportunities to use their ability. According to Khan \& Khan (2011), the founder of Pakistan Quaid-e-Azam stressed on providing the right type of education to the people of Pakistan in order to enable them to play their role for the development and progress as well as to compete with the modern world. Access to quality and equitable education is an effective tool for fighting against poverty.

According to Omoniyi (2013), education fosters self-understanding, improves the quality of lives and raises people's productivity and creativity, thus promoting entrepreneurship and technological advances. In addition, it plays very crucial roles in securing economic and social progress, thus improving income distribution to reduce poverty. First, education could promote country's productivity. Education is most important composition of country's output and exports and constitute an important ingredient in a system's capacity to borrow foreign technology effectively. At same time, education is an important contributor to technological capability and technical change in industry. Secondly, education could make greater income equality possible, Low-income people are better able to seek out economic opportunities when education becomes more broadly based, at the same time, affect per capita income growth. Third, education of parents could make family make correct decisions. For example, higher education level parents are less likely to let their children quit school and will provide children with more opportunities to acquire skills. Another example, education of the poor helps improve their food intake and make them make a healthier food choice.

In developing countries, especially in rural areas, poverty and low school achievement are very common. More than 70 percent of the world's poor are to be found in rural areas. Education for a large number of people in rural areas is crucial for achieving sustainable development and reduce poverty. Education has both economic and non-economic benefits to the educated population, and it plays an essential prerequisite for reducing poverty and living conditions of rural people (Abdulahi, 2008). It is an investment that is capable of yielding benefits that could reduce poverty efficiently (Jaiyeoba, 2007).

\section{POLICY RECOMMENDATIONS}

We could see from previous analysis Pakistan is still one of the lowest literacy rate countries in the world. It is necessary to arrange for widespread literacy for poverty alleviation. The literate family heads prefer to send their children to school and less likely to let their children to quit. Then, the general type of education is not very effective for poverty alleviation. The government should provide more vocational education and skill training at the secondary level to enable the school graduates to get self or paid employment to 
alleviate poverty, acquire practical skill and meet market demand.

Especially in rural areas, government could provide educational resource and curriculum, increase capacity of local educational organizations and local organization for poverty reduction. Due to lack of participation rural educated people in the process of poverty reduction, government should increase rural involvement, especially women education, to fill the gender gap of schooling.

A lot of poor families could not afford tuition and hence, less likely to change the current income situation. Government should strengthen incentives to improve the education of low-income families, for example, develop effective voluntary school choice programs to enable students who attend failing public schools to move to more successful schools in other districts. At the same time, government should use grants to build the capacity of schools and state departments of education to boost education of low-income children. The grants would also help develop effective programs to improve teaching and to serve students.

\section{CONCLUSION}

Poverty is a significant threat in the developing world. Education, in every sense is one of the fundamental factors of reducing poverty and achieving sustainable economic development in the world. We consider Pakistan education and poverty situation here, introduce role of education to alleviate poverty. In the end, we provide some policy implications for government, for example, to provide skill training, widespread literacy and support rural low-income children's education.

\section{REFERENCES}

[1] Becker, G. (1975). Human capital, 2nd ed. Chicago: University of Chicago, Press, 1975.

[2] Chambel, J., \& Hartl, M. (2011). Technical and Vocational Skills development for poverty alleviation. International Fund for Agricultural Development (IFAD) Policy and Technical Advisory Division

[3] Goode, R. B. (1959). Adding to the stock of physical and human capital. American Economic Review, 49(2), 147-155.

[4] Jaiyeoba, A. O. (2007). Perceived Impact Of Universal Basic Education On National Development In Nigeria. International Journal of African \& African American Studies, VI(1).

[5] Khan, J. Z., \& Khan, A. R. (2011). Quaid's Vision of Progressive Pakistan. Pakistan Journal of History and Culture, Vol.XXXII, No.1.
[6] Malik, M., A. (2010, April 18). Combating poverty through skilled based Education. Dawn.

[7] Mankiw, N. G. Romer, D. \& Weil, D. N. (1992). A Contribution to the empirics of economic growth. Quarterly Journal of Economics, 107, 407-37.

[8] Mincer, J. (1958). Investment in human capital and personal income distribution. Journal of Political Economy, 66(4), 281-302.

[9] Montecel, M. (2013, January) Education as pathway out of Poverty. INDRA Intellectual Development Research Association

[10] Nasir, M., Alam, M., \& Alam, M. T. (2016). Role of education in poverty alleviation In Pakistan. Journal of Research in Social Sciences, 4(2), 52.

[11] Omoniyi, M. B. I. (2013). The role of education in poverty alleviation and economic development: A theoretical perspective and counselling implications. British Journal of Arts and Social Sciences, 15(2), 176-185.

[12] Sachs, J. D. (2006). The end of poverty: Economic possibilities for our time. Penguin.

[13] Schultz, T. W. (1961). Investment in human capital. American Economic Review, 51(1), 1-17. 